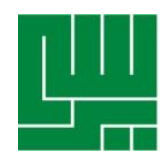

KATA KUNCI

KEYWORDS

ABSTRAK

\section{Hubungan antara Dimensi Nilai Budaya Uncertainty Avoidance dengan Intensi Berwirausaha (Studi pada Mahasiswa Suku Minangkabau)}

\section{Correlation between Uncertainty Avoidance Culture Value Dimensions with Entrepreneurial Intention (Study in Minangkabau College Students)}

\author{
Dien Nurdini Nurdin ${ }^{1}$, Gagan Hartana ${ }^{2}$, Wustari Mangundjaya ${ }^{3}$ \\ ${ }^{1,2,3}$ Fakultas Psikologi, Universitas Indonesia, Depok, Indonesia \\ Email: diennurdini@ui.ac.id
}

Budaya, Intensi Berwirausaha, Kewirausahaan, Suku

Minangkabau, Uncertainty Avoidance.

Culture, Entrepreneurship, Entrepreneurial Intention, Minangkabau Ethnic, Uncertainty Avoidance.

Banyaknya pengangguran terdidik dan minimnya jumlah wirausaha membuat lembaga pendidikan perlu melakukan upaya serius dalam mengembangkan kewirausahaan. Dalam mengembangkan kewirausahaan di Indonesia, nilai budaya perlu menjadi salah satu faktor yang diperhatikan. Dari beragam budaya yang dimiliki Indonesia, terdapat suku Minangkabau yang terkenal dari segi kewirausahaannya. Dalam penelitian ini peneliti bertujuan untuk mengetahui hubungan antara uncertainty avoidance dengan intensi berwirausaha pada mahasiswa suku Minangkabau. Penelitian ini melibatkan 118 responden mahasiswa suku Minangkabau yang sedang menempuh pendidikan di tingkat akhir Perguruan Tinggi, yaitu 66 responden berasal dari Universitas Indonesia dan 52 responden dari Institut Teknologi Bandung. Hasil penelitian menunjukkan gambaran tingkat uncertainty avoidance yang rendah dan intensi berwirausaha yang tinggi pada mahasiswa Minangkabau. Namun, yang menarik adalah hasil menunjukkan bahwa tidak ada hubungan yang signifikan antara uncertainty avoidance dengan entrepreneurial intention. Dengan demikian, intensi berwirausaha yang tinggi pada mahasiswa suku Minangkabau tidak semata-mata dipengaruhi oleh faktor kesukuannya (uncertainty avoidance). Secara praktis, implikasi hasil penelitian dapat diturunkan pada pelaksanaan pendidikan kewirausahaan. Tidak adanya korelasi menunjukkan bahwa intervensi dalam meningkatkan kewirausahaan dapat diberikan terhadap kalangan luas tanpa terpengaruh oleh faktor kesukuan. 
ABSTRACT The number of educated unemployment and inadequate number of entrepreneurs prompts educational institutions to make serious efforts in developing entrepreneurship. To develop entrepreneurship in Indonesia, culture value is an important factor to be considered. In this regard, Minangkabau is one of ethnic in Indonesia which is quite famous with entrepreneurial character. The main objective of this paper is identifying the correlation between uncertainty avoidance (UA) and entrepreneurial intention (EI) in college student from Minangkabau ethnic. With this aim, a sample of 118 university students in last year with Minangkabau ethnic (66 from University of Indonesia and 52 from Institute of Technology Bandung) has been used. Structural equations models have been used to test our hypotheses as comprehensive models. As prediction, the result of this research shows low profile of UA and high profile of EI among Minangkabau ethnicity college student. But, the interesting part is the result also shows that there is no significant correlation between UA and EI. Practically, this result shows us that high entrepreneurial intention can appear not only because the specific culture value. Implications may be derived regarding entrepreneurship education. Therefore, entrepreneurship education may be used as general to improve student's entrepreneurial intentions.

\section{PENDAHULUAN}

Kewirausahaan mendapat perhatian besar sejak tingginya persaingan lapangan pekerjaan pada berbagai bidang ekonomi dunia di era globalisasi (Ramayah \& Harun, 2005). Di Indonesia, persaingan global juga terasa semakin ketat. Bagi mahasiswa Indonesia, menjadi seorang sarjana kini bukan lagi jaminan mendapat pekerjaan. Data statistik (Biro Pusat Statistik, 2019) menunjukkan tingkat pengangguran terdidik lulusan diploma dan sarjana semakin meningkat. Berdasarkan data tersebut, per Februari 2019, tingkat pengangguran lulusan diploma (D1-D3) meningkat dari $6,4 \%$ menjadi $6,9 \%$, sedangkan tingkat pengangguran pada lulusan sarjana meningkat dari $5,0 \%$ menjadi $6,2 \%$. Tingginya jumlah pengangguran terdidik menunjukkan lapangan pekerjaan formal tidak sebanding dengan lulusan universitas setiap tahunnya. Oleh karena itu, mahasiswa perlu mempertimbangkan berwirausaha sebagai alternatif pilihan karier.

Di sisi lain, minat berwirausaha di Indonesia perlu ditingkatkan. Direktur Eksekutif Asosiasi Pengusaha Indonesia, Danang Girindrawardana, menyebutkan saat ini jumlah wirausaha di Indonesia hanya $3,1 \%$ dari jumlah masyarakat di usia produktif di Indonesia. Padahal, tingkat wirausaha di negara-negara maju bisa mencapai 14\%. (CNN Indonesia, 2018). Berdasarkan indikator dari hasil penelitian Global Entrepreneurship Index tahun 2018 yang mengukur dinamika kewirausahaan suatu negara, Indonesia berada di tingkat ke 98 dari 137 negara atau jauh di bawah Thailand, Malaysia, dan Singapura.

Penelitian terkait pengembangan kewirausahaan penting dilakukan pada mahasiswa karena mereka adalah cikal bakal dari wirausahawan di masa depan (Ramayah \& Harun, 2005). Minat berwirausaha pada mahasiswa dapat dilihat antara lain melalui intensi berwirausaha (entrepreneurial intention), disadari sebagai elemen kunci untuk mengetahui proses pembentukan usaha yang baru (Bird, 1988).

Di sisi lain, kemampuan bertoleransi terhadap keadaan yang tidak pasti dan ambigu (tolerance for ambiguity) termasuk dalam salah satu karakteristik yang sering terlihat pada pelaku wirausaha (Zimmerer \& Scarborough, 2002). Temuan penelitian Bhide (dalam Zimmerer \& Scarborough, 
2002), seorang ahli kewirausahaan, menyatakan bahwa seorang pelaku wirausaha perlu berkomitmen pada sesuatu walau belum ada kepastian mengenai keuntungan yang akan diperoleh. Hal ini menunjukkan bahwa dalam wirausaha diperlukan kesanggupan dalam menghadapi keadaan yang tidak pasti. Dengan kata lain, kemampuan seseorang dalam berwirausaha dipengaruhi oleh tingkat penghindaran situasi tidak pasti (uncertainty avoidance) seseorang.

Sejauh ini, penelitian tentang hubungan penghindaran situasi tidak pasti dengan tingkat kepemilikan bisnis pada 21 negara menunjukkan hasil bahwa kewirausahaan lebih dominan muncul pada lingkungan yang memiliki tingkat penghindaran situasi tidak pasti yang rendah (Wennekers dkk.,2007). Penelitian lain juga mendukung bahwa penghindaran situasi tidak pasti dengan level yang rendah berkaitan dengan kewirausahaan baik yang indigenous (Redpath \& Nielsen, 1997) maupun yang terbentuk secara umum (McGrath dkk.,1992).

Berdasarkan penjelasan mengenai intensi berwirausaha dan uncertainty avoidance, maka peneliti berasumsi bahwa terdapat hubungan antara uncertainty avoidance dengan intensi berwirausaha. Hubungan ini menarik diteliti lebih jauh pada suku Minangkabau yang diduga kuat tingkat kewirausahaannya. Dengan demikian, penelitian ini bertujuan untuk melihat hubungan antara uncertainty avoidance dengan intensi berwirausaha pada mahasiswa suku Minangkabau, gambaran uncertainty avoidance pada mahasiswa suku Minangkabau, serta juga gambaran intensi berwirausaha pada mahasiswa suku Minangkabau.

Ajzen (1975) mendefinisikan intensi (intention) sebagai kecenderungan seseorang untuk menampilkan tingkah laku di masa depan. Seseorang memiliki kecenderungan kuat menampilkan tingkah laku ketika dianggap memungkinkan dan juga diinginkan. Dalam hal ini, intensi berwirausaha dapat dijelaskan dengan cara yang sama, yaitu intensi seseorang dalam berwirausaha akan lebih tinggi ketika tingkah laku berwirausaha tersebut dianggap memungkinkan untuk dilakukan dan individu memiliki keinginan untuk melakukan kegiatan berwirausaha (Hisrich dkk.,2008).

Model intensi berwirausaha (Linan, 2008) merupakan pendekatan terbaru yang menjelaskan intensi berwirausaha. Model ini adalah pengembangan dari teori planned behavior dari Ajzen dan Fishbein (1991). Berdasarkan teori planned behavior, intensi merupakan fungsi dari tiga faktor dasar, yaitu sikap personal (personal attitude), norma subjektif (perceived social norms), dan kontrol tingkah laku yang dipersepsikan (perceived behavioral control). Meski demikian, teori planned behavior dari Ajzen dan Fishbein (1991) tersebut tidak mencakup beberapa kombinasi dari faktor lingkungan yang memiliki peran dalam kewirausahaan, seperti kondisi sosioekonomi, keahlian bisnis dan berwirausaha, bantuan keuangan, maupun faktor lainnya yang berbeda di setiap negara (Gnyawali \& Fogel, 1994, Davidsson \& Henkson, 2002; dalam Linan, 2008). Oleh karena itu, Linan mengembangkan model intensi berwirausaha (entrepeneurial intention model) untuk memahami pengaruh sosial dan persepsi keahlian seseorang (Linan, 2008).

Dalam model intensi berwirausaha (Linan, 2008) terdapat faktor yang mempengaruhi secara tidak langsung, yaitu melalui dimensi ketertarikan personal, norma subjektif, dan kontrol tingkah laku yang dipersepsikan. Faktor tersebut terdiri dari penilaian lingkungan (closer valuation), penilaian budaya (social valuation), dan keahlian kewirausahaan (entrepreneurial skill).

Dalam penilaian lingkungan, individu secara umum dinilai dapat terpengaruh oleh lingkungan terdekatnya, yaitu hubungan dekat dengan keluarga atau teman. Hal ini dapat mempengaruhi perceived desirability (keinginan yang dipersepsikan) secara langsung sebagai konsekuensi atas 
penyesuaian nilai kognitif dan persepsi keyakinan individu mengenai suatu karier (Uphoff, 2000; Grootaert dan Bastelaer 2001; dalam Linan, 2008). Dengan demikian lingkungan dekat seseorang berkaitan dengan ketertarikan personal, norma subjektif, dan gender. Dalam hal ini, kontrol tingkah laku yang dipersepsikan tidak begitu terpengaruh oleh penilaian lingkungan (Linan, 2008).

Faktor penilaian budaya memiliki peran penting dalam menentukan tingkah laku kewirausahaan (Zahra dkk., 1999; dalam Linan, 2008). Hal ini didukung pernyataan Thomas dan Muller (2000, dalam Linan, 2008) bahwa budaya dapat memperkuat karakteristik personal, membentuk perkembangan sifat kepribadian dan kapasitas seseorang, penilaian terhadap norma, dan kemampuan mempersepsikan aktivitas kewirausahaan. Dengan demikian, penilaian sosial dapat mempengaruhi norma subjektif dan kontrol tingkah laku yang dipersepsikan.

Persepsi

kewirausahaan mengenai keahlian menunjukkan tingkat kepercayaan responden bahwa dirinya berada pada level yang memenuhi keahlian tertentu berkaitan dengan kegiatan berwirausaha. Memiliki keahlian kewirausahaan dapat membuat individu merasa lebih mampu untuk memulai suatu usaha (Denoble dkk.,. 1999, dalam Linan, 2008). Keahlian tersebut juga berhubungan dengan ketertarikan personal dan norma subjektif yang lebih tinggi (Scherer dkk., 1991; Casrud, 1992; Boyd dan Vozikis 1994; dalam Linan, 2008).

Secara keseluruhan, model intensi berwirausaha dapat dilihat pada Gambar 1 .

Tinjauan pustaka yang berikut adalah tentang dimensi budaya uncertainty avoidance. Dimensi budaya merupakan aspek budaya yang dapat diukur dan berfungsi sebagai alat untuk membandingkannya dengan budaya lain (Ndraha, 2005). Dengan mereduksi domain nilai ke dalam dimensi, akan lebih mudah dalam mengukur dan membandingkannya dengan budaya lain (Hofstede \& Hofstede, 2005).

Gambar1

Model Intensi Berwirausaha

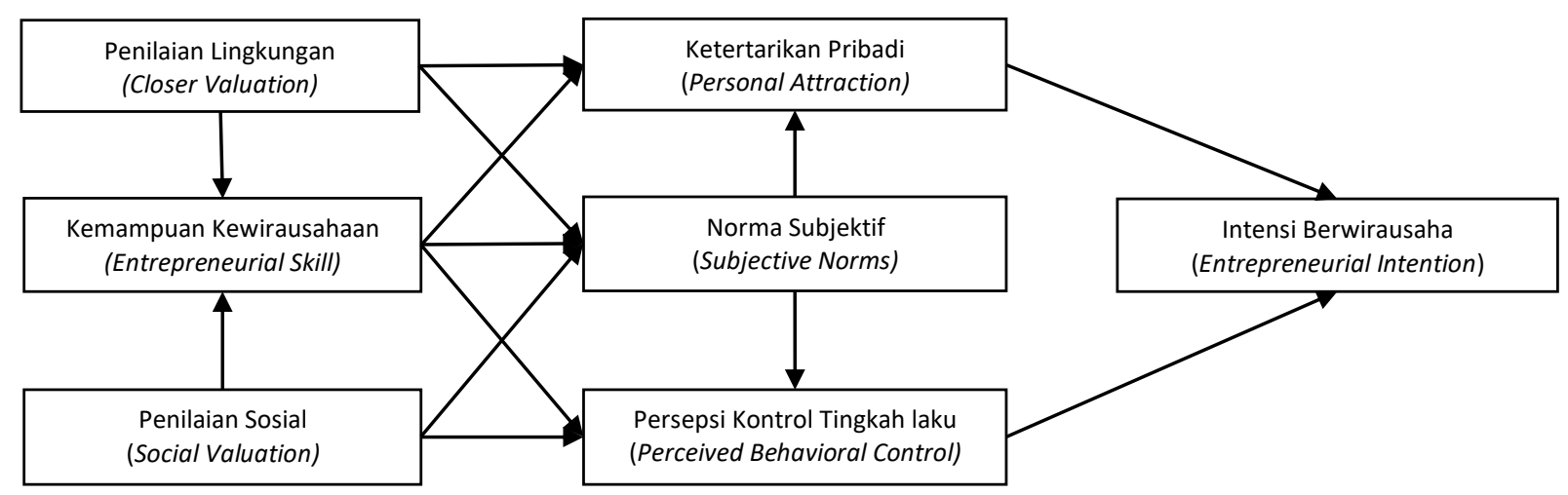

Dari penelitian Hofstede pada rentang tahun 1967-2001 terhadap pegawai perusahaan IBM di 74 negara, diperoleh empat dimensi budaya yang menjadi pembeda antar budaya (Hofstede \&
Hofstede, 2005), yaitu power distance (PD), uncertainty avoidance (UA), individualismcollectivism (I/C), masculinity-femininity (MAS/FEM), time orientation. Keempat dimensi Hofstede ini dapat dilihat secara 
terpisah. Dari keempat dimensi tersebut, peneliti hanya akan memfokuskan pada dimensi yang diduga erat keterkaitannya dengan kewirausahaan, yaitu uncertainty avoidance.

Hofstede dan Hofstede (2005) mendefinisikan uncertainty avoidance sebagai "the extent to which the members of a culture feel threatened by ambigous or unknown situations". Berdasarkan definisi tersebut, maka uncertainty avoidance (UA) dapat dimaknai sebagai besarnya perasaan terancam yang dialami anggota masyarakat budaya tertentu oleh situasi yang tidak pasti atau ambigu.

Ketidakpastian yang di luar batas dapat menyebabkan kecemasan yang tidak dapat ditoleransi. Inti dari ketidakpastian adalah suatu pengalaman atau perasaan yang subjektif. Perasaan ini ditunjukkan melalui stres, rasa gelisah, dan kebutuhan akan sesuatu untuk dapat menentukan kepastian, seperti kebutuhan peraturan tertulis dan tidak tertulis. Perasaan ketidakpastian tidak hanya bersifat personal, tetapi juga terbagi dengan anggota lainnya dalam suatu masyarakat. Perasaan ini diwarisi dan dapat dipelajari melalui kelompok dasar dalam suatu budaya, seperti masyarakat, sekolah, dan negara (Hofstede, 1997). Pola perilaku dari suatu masyarakat dapat berbeda dengan anggota dari masyarakat yang lain.

Terdapat dua karakteristik UA di masyarakat, yaitu masyarakat dengan UA tinggi dan rendah. Masyarakat dengan UA yang tinggi merasa nyaman bila masa kini dan masa depan mereka berada dalam situasi dan kondisi yang jelas. Mereka cenderung merasa cemas terhadap ketidakpastian hidup dan memandangnya sebagai sesuatu yang mengancam dan harus dilawan. Masyarakat UA tinggi mementingkan adanya peraturan, institusi hukum, dan kontrol yang dapat mengurangi ketidakpastian. (Hofstede \& Hofstede, 2005). Sementara itu, orang yang memiliki UA yang rendah akan tetap merasa nyaman walaupun mereka tidak memiliki kepastian terhadap masa kini maupun masa depan (Wagner \& Hollenbeck, 1995). Sikap tersebut ditunjukkan dengan ciri-ciri pada masyarakat UA rendah, yaitu menerima bahwa hidup memang dipenuhi oleh ketidakpastian dan cara menghadapinya adalah dengan menjalani masa kini, memungkinkan untuk mengambil risiko dalam hidup, memiliki toleransi terhadap perbedaan, dapat menngatur konflik dan kompetisi sebagai suatu hal yang membangun, dan memiliki sedikit peraturan yang benar-benar dipakai dan perlu (Wagner \& Hollenbeck, 1995).

Berdasarkan penelitian Hofstede dan Hofstede (2005) mengenai dimensi budaya, Indonesia memperoleh posisi 60 dari 74 negara untuk dimensi UA dengan skor yang diperoleh 48, di mana skor yang lebih kecil dari 56 sudah tergolong ke dalam tingkat UA yang rendah. Dengan demikian, Indonesia tergolong memiliki tingkat UA yang rendah. Ciri orang dengan UA rendah adalah dapat menerima ketidakpastian hidup dan menjalani keadaan yang terjadi di hari ini, menganggap perbedaan pendapat sebagai sesuatu yang dapat ditoleransi, baik dalam inovasi, serta terlibat dalam pengambilan keputusan (Hofstede \& Hofstede, 2005).

Akan tetapi, Indonesia terdiri dari berbagai macam suku bangsa yang memiliki nilai budaya yang berbeda pula. Dengan demikian, dapat dikatakan bahwa penelitian Hofstede dan Hofstede (2005) lebih menggambarkan budaya Indonesia secara umum. Lebih lanjut, Pranadhini (2006) mengadakan penelitian mengenai UA pada suku Minangkabau dengan responden yang terdiri dari 73 pegawai Bank X di Sumatera Barat. Hasil penelitian tersebut menunjukkan suku Minangkabau memiliki tingkat UA yang tinggi. Sedangkan penelitian lainnya mengenai UA pada suku Minangkabau (Octaviani, 2006) menunjukkan kategori UA yang dimiliki suku Minangkabau tergolong rendah. Adanya perbedaan hasil penelitian tersebut menambah implikasi hasil penelitian ini yang menggambarkan secara komprehensif mengenai dimensi UA pada suku Minangkabau.

Di sisi lain, penelitian tahun 1976 hingga tahun 2004 tentang hubungan uncertainty 
avoidance dengan tingkat kepemilikan bisnis pada 21 negara menunjukkan hasil bahwa kewirausahaan lebih dominan muncul pada lingkungan yang memiliki tingkat uncertainty avoidance yang rendah (Wennekers dkk., 2007). Penelitian lain juga mendukung bahwa uncertainty avoidance dengan level yang rendah berkaitan dengan kewirausahaan baik yang indigenous (Redpath \& Nielsen, 1997) maupun yang terbentuk secara umum (McGrath dkk.,1992). Sementara itu, intensi berwirausaha (entrepreneurial intention) disadari sebagai elemen kunci untuk mengetahui proses pembentukan usaha yang baru (Bird, 1988, dalam Linan dkk.,2008). Dengan demikian, seseorang dengan tingkat UA yang rendah diduga memiliki tingkat intensi yang tinggi dalam berwirausaha.

Berdasarkan penjelasan mengenai intensi berwirausaha dan UA, maka peneliti berasumsi bahwa terdapat hubungan antara UA dengan intensi berwirausaha. Semakin tinggi UA maka individu akan cenderung memiliki intensi berwirausaha yang rendah, sebaliknya semakin rendah UA maka individu akan cenderung memiliki intensi berwirausaha yang tinggi. Hubungan ini menarik diteliti lebih jauh pada suku Minangkabau yang diduga kuat tingkat kewirausahaannya.

Dalam masyarakat Minangkabau, perekonomian sangat dipentingkan. Hal tersebut didasari adanya pemahaman pada masyarakat Minangkabau bahwa dasar ekonomi yang sehat akan membentuk masyarakat yang makmur dan kebudayaan yang berkembang serta pembangunan yang terlaksana (Hakimy, 1991). Pengertian tentang ekonomi itulah yang membuat orang Minangkabau banyak pergi merantau ke daerah lain (Hakimy, 1991). Budaya merantau ini bukan disebabkan oleh tempat asal yang miskin atau kehidupan yang serba susah, tetapi didorong oleh rasa untuk memelihara dan menambah harta pusaka. Kekayaan yang diperoleh di rantau itu tidak pergunakan di daerah rantau melainkan dibawa ke kampung halaman (Hakimy, 1991). Dalam hal ini terdapatlah perlombaan yang baik sesama orang Minangkabau dalam memperbaiki keadaan ekonomi kaum dan daerahnya.

Kepergian orang-orang Minangkabau ke perantauan tidak dipandang merugikan masyarakat, justru menguntungkan, mengandung harapan rejeki, dan kekayaan serta ilmu pengetahuan yang akan dibawa kelak ke kampung halaman untuk disumbangkan dan dikembangkannya (Hakimy, 1991). Oleh karena itu, banyak sekali mahasiswa Minangkabau yang dapat ditemukan di daerah perantauan yang sedang mencari ilmu maupun sekaligus merintis usaha. Mahasiswa Minangkabau ini dapat ditemukan di berbagai kota besar di Indonesia, antara lain di kota Depok dan Bandung.

\section{METODE PENELITIAN \\ Partisipan}

Subjek penelitian bersuku Minangkabau dan memiliki orang tua bersuku Minangkabau, rentang usia 19-24 tahun, dan sedang menjalani tahun terakhir di perguruan tinggi. Pengambilan data penelitian dilakukan di dua kampus kota besar Indonesia, yaitu di kota Depok dan Bandung. Jumlah subyek terdiri dari 78 orang mahasiswa Depok, dan 40 orang mahasiswa Bandung, dengan total 118 mahasiswa. Teknik pengambilan sampel adalah accidental sampling.

\section{Instrumen}

Terdapat dua variabel yang diteliti dalam penelitian ini, yaitu uncertainty avoidance dan intensi berwirausaha. Alat pengumpulan data yang dikumpulkan adalah berupa kuesioner dengan metode self-report yang disusun berupa skala Likert.

Alat ukur uncertainty avoidance yang digunakan pada penelitian ini dikembangkan berdasarkan teori dimensi budaya nasional dari Geert Hofstede (Hofstede \& Hofstede, 2005), khususnya dalam dimensi uncertainty avoidance. Kuesioner uncertainty avoidance ini adalah hasil modifikasi dan pengembangan dari skala Values Survey Module 1994 (VSM-1994) 
yang disusun oleh Hofstede. Kuesioner ini terdiri dari 17 item yang kemudian dieliminasi menjadi 11 item setelah mengalami validitas dan reliabilitas alat ukur. Format respon yang dipergunakan dalam alat ukur ini adalah format respon Likert 1-5. Perhitungan reliabilitas yang dilakukan pada 11 item yang valid memperoleh nilai reliabilitas alat ukur uncertainty avoidance sebesar 0,844 .

Alat ukur intensi berwirausaha yang digunakan pada penelitian ini adalah Entrepreneurial Intention Questionnaire versi 3 (Linan, 2008). Format respon yang dipergunakan dalam alat ukur ini adalah format respon Likert $1-7$ yang menyatakan tingkat persetujuan responden dari 1 (sangat tidak setuju) dan 7 (sangat setuju). Kuesioner yang digunakan dalam penelitian ini terdiri dari 37 item yang kemudian dieliminasi menjadi 27 item setelah dilakukan uji validitas dan reliabilitas item. Perolehan nilai reliabilitas item valid dari alat ukur intensi berwirausaha sebesar 0,9452 .

Tingkat uncertainty avoidance dan intensi berwirausaha yang dimiliki responden ditentukan menggunakan norma berupa nilai rata-rata dari kelompok standar yang memiliki kriteria tinggi dan rendah. Kelompok standar ini merupakan kelompok kriteria pada uji coba alat ukur yang diperoleh berdasarkan informasi orangorang terdekat (significant others) yang mengetahui karakteristik responden. Untuk alat ukur intensi berwirausaha, peneliti melakukan uji coba pada 10 responden yang dinyatakan memiliki kriteria intensi berwirausaha rendah dan 15 responden yang dinyatakan memiliki kriteria intensi berwirausaha tinggi. Sementara untuk alat ukur uncertainty avoidance, peneliti melakukan uji coba pada 10 responden yang dinyatakan memiliki kriteria uncertainty avoidance rendah dan 10 responden yang dinyatakan memiliki kriteria uncertainty avoidance tinggi.

Norma yang digunakan dalam penelitian tergolong dalam reference norms. Norma yang digunakan dalam menentukan tingkat uncertainty avoidance dan intensi berwirausaha responden dapat dilihat pada Tabel 1.

Tabel 1

Pengkategorian Skor UA

\begin{tabular}{lll}
\hline \multicolumn{1}{c}{ Kelompok } & \multicolumn{1}{c}{ Mean $( \pm)$ 1 SD } & \multicolumn{1}{c}{ Skor } \\
\hline UA Tinggi & $3,46 \pm 0,273$ & 3,187 s.d. 3,733 \\
\hline UA Rendah & $2,67 \pm 0,489$ & 2,181 s.d. 3,159 \\
\hline EI Tinggi & $5,153+0,503$ & 4,65 s.d. 5,656 \\
\hline EI Rendah & $3,634+0,764$ & 2,87 s.d. 4,398 \\
\hline
\end{tabular}

\section{Teknik Analisis Data}

Dalam rangka mengetahui apakah terdapat hubungan yang signifikan antara UA dengan intensi berwirausaha dilihat secara sederhana melalui tabulasi silang dan dianalisis lebih lanjut menggunakan analisis hubungan kausal dalam structural equation model. Nilai korelasi ditafsirkan dengan tanda positif atau negatif dan nilai signifikansi. Sedangkan gambaran umum dari responden dilakukan dengan metode statistika deskriptif yaitu frekuensi dan persentase.

\begin{abstract}
ANALISIS DAN HASIL
Berdasarkan hasil tabulasi silang pada Tabel 2 dapat terlihat bahwa sebagian besar responden (yaitu 54 dari 118 responden) memiliki tingkat UA rendah dan intensi berwirausaha tinggi. Namun demikian, hal tersebut tidak diimbangi dengan banyaknya responden yang memiliki tingkat UA tinggi dan intensi berwirausaha rendah (yang hanya sebesar 10 dari 118 responden).
\end{abstract}


Tabel 2

Tabulasi Silang (cross-tabulation) antara Intensi Berwirausaha dan UA

\begin{tabular}{llll}
\hline & EI Tinggi & EI Rendah & Total \\
\hline UA Tinggi & 24 orang & 10 orang & 34 orang \\
\hline UA Rendah & 54 orang & 30 orang & 84 orang \\
\hline Total & 78 orang & 40 orang & 118 orang \\
\hline
\end{tabular}

Sementara itu, pengolahan data yang berkaitan dengan pengujian hipotesis dilakukan dengan analisis structural equation modeling (SEM) dengan bantuan program Lisrel versi 8.50. Hal ini dilakukan untuk menjawab masalah penelitian, yaitu melihat hubungan antara uncertainty avoidance dengan intensi berwirausaha secara simultan melalui pendekatan model intensi berwirausaha (Linan, 2008). SEM memiliki kemampuan untuk menunjukkan konsep-konsep yang tidak teramati serta hubungan yang ada di dalamnya, dan perhitungan terhadap kesalahan pengukuran (Wijanto, 2008).

Variabel laten adalah konsep yang dihipotesiskan atau yang tidak teramati, dan hanya dapat didekati melalui variabelvariabel teramati. Variabel teramati dapat diperoleh melalui berbagai metode pengumpulan data, salah satunya adalah survei (kuesioner). Pendekatan variabel teramati hampir selalu memiliki kesalahan pengukuran (measurement errors) dan dapat diestimasi menggunakan fasilitas-fasilitas yang ada dalam SEM (Wijanto, 2008). Baik model intensi berwirausaha maupun uncertainty avoidance memiliki variabel yang tidak teramati secara langsung (variabel laten) seperti closer valuation, entrepreneur skill, social valuation, personal attraction, subjective norms, perceived behavioral control, entrepreneurial intention, dan uncertainty avoidance.

Perhitungan hubungan pada variabel laten dapat dilakukan secara simultan sehingga dapat mengurangi error (residu) pada pengukuran menggunakan SEM. Kline dan Klammer (2001,dalam Wijanto, 2008), lebih mendorong menggunakan penggunaan
SEM dibandingkan regresi berganda antara lain karena pertimbangan bahwa SEM memeriksa hubungan antara variabel sebagai sebuah unit, tidak seperti pada regresi berganda yang pendekatannya sedikit demi sedikit. Selain itu, asumsi pengukuran yang andal dan sempurna pada regresi berganda tidak dapat dipertahankan, dan pengukuran dengan kesalahan dapat ditangani dengan mudah oleh SEM.

SEM memiliki dua jenis model, yaitu model struktural dan model pengukuran. Model struktural mendefinisikan hubunganhubungan dalam variabel laten secara simultan. Sementara model pengukuran menggambarkan hubungan variabelvariabel teramati dengan variabel laten seperti analisis faktor pada psikometri dan sosiometri (Wijanto, 2008). Penelitian ini bertujuan untuk mengetahui hubungan dalam variabel laten dan bukan untuk menguji model. Oleh karena itu, peneliti menggunakan model struktural karena ingin mengetahui hubungan UA dengan intensi berwirausaha secara simultan.

Di dalam analisis SEM diperlukan spesifikasi model yang dilakukan terhadap permasalahan yang diteliti sesuai dengan teori yang mendasarinya (Wijanto, 2008). Spesifikasi model struktural dilakukan dengan mendefinisikan hubungan di antara variabel-variabel laten. Dalam penelitian ini, peneliti menggunakan pendekatan dari model intensi berwirausaha (Linan \& Chen, 2009) untuk mendefinisikan hubungan antara variabel intensi dan menambahkan variabel UA pada model tersebut untuk dapat melihat hubungan (effect) UA terhadap intensi berwirausaha secara simultan. 
Tahapan selanjutnya adalah menetapkan gambaran path diagram untuk mendapatkan indeks-indeks yang menggambarkan adanya hubungan dan besarnya hubungan antar variabel yang diamati. Adanya hubungan dilihat dari indeks yang signifikan (t-value $>1,96$ ). Sedangkan besarnya hubungan dapat dilihat dari indeks Universitas Indonesia 50 standardized solution yang memiliki nilai varian sama dan nilai maksimumnya adalah 1 (Wijanto, 2008).
Oleh karena itu, analisis hubungan kausal dalam model struktural dapat dilakukan untuk menggambarkan hubungan yang ada antara variabel laten. Hubungan antar variabel laten dapat dilihat dari indeks nilai-t (t-test) yang signifikan pada persamaan struktural (structural equation). Besarnya indeks nilai-t antara UA terhadap Intensi Berwirausaha dalam model struktural dapat dilihat pada Tabel 3.

Tabel 3

Nilai-t dan Koefisien Lintasan UA ke Intensi Berwirausaha

\begin{tabular}{lllll}
\hline Path & Estimasi & Nilai-t & Kesimpulan & Ket. \\
\hline UA $\rightarrow$ EI & 0.048 & 0.66 & Tidak Signifikan & $\mathrm{R}=0.029$ \\
& & & & R2 $=0.000841$ \\
\hline
\end{tabular}

Menurut Guilford, jika jumlah degree of dreedom di atas 100, maka nilai-t dapat dianggap signifikan jika lebih besar dari 1,96. Pada persamaan struktural dari Tabel 2. diketahui bahwa nilai-t dari koefisien UA adalah $0,66<1,96$, sehingga dapat disimpulkan koefisien UA (koefisien lintasan UA ke intensi berwirausaha) yaitu 0,048 adalah tidak signifikan. Hal ini menandakan bahwa UA tidak mempengaruhi intensi berwirausaha seseorang secara signifikan.

Berdasarkan nilai-t yang diperoleh, maka selanjutnya dapat dihitung nilai $\mathrm{R}$ dan $\mathrm{R}^{2}$ dengan degrees of freedom sebesar 513 . Berdasarkan nilai $\mathrm{R}^{2}$, maka dapat diketahui bahwa sebesar $0.08 \%$ variasi pada variabel intensi berwirausaha (EI) dijelaskan oleh variasi dari variabel UA. Hal ini menunjukkan kecilnya pengaruh yang ditimbulkan UA terhadap intensi berwirausaha (EI).

Selanjutnya untuk mengetahui gambaran tingkat uncertainty avoidance responden, maka peneliti menentukan rentang skor 3,187 hingga 3,733 ke dalam kategori UA tinggi dan rentang skor 2,181 hingga 3,159 ke dalam kategori UA rendah. Hasilnya adalah 90 orang dari 118 responden tergolong dalam kategori UA yang rendah, sedangkan 28 orang lainnya tergolong dalam kategori UA tinggi. Dengan demikian sebagian besar mahasiswa suku Minangkabau memiliki nilai UA yang rendah.

Demikian pula untuk mengetahui gambaran tingkat intensi berwirausaha responden, maka peneliti menentukan rentang skor 4,65 hingga 5,65 tergolong dalam kategori intensi berwirausaha tinggi dan rentang skor 2,87 hingga 4,398 tergolong dalam kategori intensi berwirausaha rendah. Hasil menunjukkan bahwa 78 dari 118 responden tergolong dalam kategori intensi berwirausaha tinggi, sedangkan 40 responden lainnya tergolong pada kategori intensi berwirausaha rendah. Dengan demikian, dapat dikatakan bahwa sebagian besar mahasiswa suku Minangkabau memiliki intensi berwirausaha yang tinggi.

\section{DISKUSI}

Hasil penelitian menunjukkan bahwa tidak terdapat nilai koefisien korelasi yang signifikan antara dimensi uncertainty avoidance dengan intensi berwirausaha pada mahasiswa suku Minangkabau. Hasil 
penelitian ini mengandung arti bahwa pada sampel penelitian ini, nilai uncertainty avoidance tidak berhubungan dengan intensi berwirausaha seseorang. Dengan demikian, intensi berwirausaha pada mahasiswa suku Minangkabau tidak ditentukan melalui kecenderungan mereka untuk merasa nyaman pada situasi yang tidak pasti.

Penelitian Wennekers dkk. (2007) menjelaskan bahwa kewirausahaan lebih dominan muncul pada lingkungan yang memiliki tingkat uncertainty avoidance yang rendah. Kata 'lebih dominan' disini perlu diperhatikan, dimana hal ini sesuai dengan hasil penelitian bahwa intensi berwirausaha pada mahasiswa Minangkabau memang cenderung tinggi, dan tingkat UA responden juga cenderung rendah. Namun demikian, belum tentu keduanya berkaitan, karena berdasarkan hasil penelitian, intensi berwirausaha lebih dipengaruhi oleh nilainilai budaya dan lingkungan dari mahasiswa Minangkabau itu sendiri.

Berdasarkan analisis yang dilakukan, kedua faktor lain dari model intensi berwirausaha, yaitu faktor penilaian lingkungan (closer valuation) dan penilaian sosial (social valuation) dinilai lebih berpengaruh dalam menentukan intensi berwirausaha dibandingkan dengan nilai uncertainty avoidance.

Dari kesimpulan diperoleh hasil bahwa mahasiswa suku Minangkabau cenderung memiliki tingkat uncertainty avoidance yang rendah. Masyarakat dengan UA rendah akan tetap merasa nyaman walaupun mereka tidak memiliki kepastian terhadap masa kini maupun masa depan dan memandang perbedaan bukan sebagai hal yang mengancam (Wagner \& Hollenbeck, 1995).

Hasil penelitian ini sejalan dengan penelitian Octaviani (2006) terhadap pegawai bank, dimana hasil penelitian menunjukkan bahwa kategori UA yang dimiliki suku Minangkabau tergolong rendah. Lebih lanjut, hasil penelitian dapat dijelaskan melalui gambaran budaya pada suku Minangkabau.

Dalam budaya Minangkabau, sifat yang dimiliki adat Minangkabau adalah "tetap" dan "berubah", yaitu meskipun prinsip adat dan ajarannya bersifat tetap namun dapat berubah dalam "penerapannya" sesuai dengan situasi dan kondisi yang dilaluinya (Hakimy, 1991). Dengan demikian adat Minangkabau tidak memandang perbedaan sebagai sesuatu yang mengancam.

Selain itu, masyarakat Minangkabau juga menekankan pada pentingnya perekonomian (Hakimy, 1991). Sehingga masyarakat Minangkabau tidak ragu untuk mencoba sesuatu yang berisiko untuk dapat memenuhi perekonomian mereka. Budaya merantau yang dipandang positif dalam suku Minangkabau juga menunjukkan bahwa mereka berani menghadapi risiko untuk mengalami ketidakpastian di tempat rantau.

Dari kesimpulan diperoleh hasil bahwa mahasiswa Minangkabau memiliki intensi berwirausaha yang tinggi. Hasil penelitian ini sejalan dengan budaya mereka yang menganggap penting perekonomian (Hakimy, 1991). Pentingnya perekonomian juga erat dengan budaya merantau yang bertujuan untuk mencari kekayaan dan ilmu untuk dibawa kembali ke kampung halaman (Hakimy, 1991). Sebagian masyarakat Minangkabau yang merantau ini banyak yang memilih berwirausaha di daerah perantauan. Dengan demikian, sifat-sifat kewirausahaan erat kaitannya dengan nilai budaya dari suku Minangkabau itu sendiri.

\section{SIMPULAN}

Hasil penelitian menunjukkan bahwa tingkat uncertainty avoidance mahasiswa suku Minangkabau adalah rendah. Masyarakat dengan tingkat uncertainty avoidance rendah cenderung merasa nyaman berada dalam situasi dan kondisi yang tidak pasti, selain itu mereka juga memandang perbedaan sebagai hal yang tidak mengancam.

Hasil penelitian juga menunjukkan tingkat intensi berwirausaha mahasiswa suku Minangkabau adalah tinggi. Dengan demikian kecenderungan seseorang untuk memulai usaha pada mahasiswa suku Minangkabau cenderung tinggi. 
Menariknya, walaupun tingkat uncertainty avoidance rendah dan intensi berwirausaha tinggi pada mahasiswa suku Minangkabau, namun hasil penelitian menunjukkan tidak terdapat nilai koefisien korelasi yang signifikan antara keduanya. Dengan dimikian dapat disimpulkan bahwa tidak terdapat hubungan antara uncertainty avoidance dengan intensi berwirausaha pada mahasiswa suku Minangkabau. Intensi berwirausaha yang tinggi pada mahasiswa suku Minangkabau tidak semata-mata dipengaruhi oleh faktor kesukuannya (uncertainty avoidance).

\section{SARAN}

Secara praktis, hasil penelitian menunjukkan bahwa intensi berwirausaha pada mahasiswa suku Minangkabau termasuk tinggi. Dengan demikian dukungan dan arahan yang tepat dari pimpinan Universitas maupun pemerintah berupa seminar kewirausahaan, pelatihan wirausaha, dan bantuan pinjaman modal yang diberikan dapat secara efektif kepada mahasiswa suku Minangkabau tersebut dapat menghasilkan calon-calon wirausaha di masa depan yang menyumbang peran dalam membangun perekonomian Indonesia.

Selain itu, hasil penelitian menunjukkan tidak adanya hubungan antara uncertainty avoidance dengan intensi berwirausaha. Dengan demikian alat ukur intensi berwirausaha dapat digunakan secara luas dalam memberi gambaran mahasiswa mana yang dapat dikembangkan menjadi seorang wirausaha. Hal ini akan membantu seluruh pihak terkait ketika menentukan target pemberian bantuan modal dan dukungan lainnya dalam mengembangkan cikal bakal wirausaha. Pendidikan kewirausahaan pun dapat diberikan terhadap kalangan yang luas tanpa terpengaruh oleh faktor kesukuan.

\section{DAFTAR PUSTAKA}

Ajzen, I. (1991). The theory of planned behavior. Organizational Behavior and Human Decision Processes, 50(2), 179211.
Ajzen, I., \& Fishbein, M. (1975). Belief, attitude, intention, and behavior. Addison-Wisley Publishing Company.

Badan Pusat Statistik. (2019, Mei 6). Februari 2019: Tingkat pengangguran terbuka (TPT) sebesar 5,01 persen. https://www.bps.go.id/pressrelease/201 9/05/06/1564/februari-2019-tingkatpengangguran-terbuka--tpt-sebesar-5-01-persen.html.

CNN Indonesia. (2018, Oktober 19). Hanya 3,1 persen penduduk di RI yang wirausaha. CNN Indonesia. https://www.cnnindonesia.com/ekonom i/20181018210657-92-339664/hanya31-persen-penduduk-produktif-di-riyang-wirausaha.

Davidsson, P., \& Henkson, M. (2002). Determinants of the prevalence of startups and high-growth firms. Small Business Economics, 19(2), 81-104.

Gnyawali, D. R., \& Fogel, D. S. (1994). Environments for entrepreneurship development: Key dimensions and research implications. Entrepreneurship Theory and Practice, 18(4), 43-62.

Hakimy, I. (1991). Rangkaian mustika adat basandi syarak di Minangkabau. Rosdakarya.

Hisrich, R. D., Peters, M. P., \& Shepherd, D. A. (2008). Entrepreneurship ( $7^{\text {th }}$ ed.). McGraw Hill.

Hofstede, G. \& Hofstede, G. (2005). Cultures and organizations: Software of the mind (Rev 2nd ed.). McGraw Hill.

Hofstede, G. (1997). Cultures and organizations: Software of the mind. McGraw Hill.

Linan, F. (2008). Skill and value perceptions: how do they affect entrepreneurial intentions?

International Journal of Mangement and Entrepreneurship, 4(3), 257-272.

Linan, F., \& Chen, Y.W. (2009). Development and cross-cultural 
application of a specific instrument to measure entrepreneurial intentions. Entrepreneurship Theory and Practice,33(3), 593-617. (in press).

Linan, F., Urbano, D., \& Guerrero, M. (2007). Regional variations in entrepeneurial cognitions: Start-up intentions of university students in Spain. Entrepreneurship and Regional Development, 23(3-4), 187-215.

McGrath, R.G., MacMillan, I.C., \& Scheinberg. (1992). Elitists, risk-takers, and rugged individualists? An exploratory analysis of cultural differences between entrepreneurs and non-entrepreneurs. Journal of Business Venturing, 7(2), 115-135.

Ndraha, T. (2005). Teori budaya organisasi. Rineka Cipta.

Octaviani, M. (2006). Profil komitmen organisasi dan kaitannya dengan uncertainty avoidance pada suku Minang dan Jawa [Skripsi tidak diterbitkan)]. Universitas Indonesia.

Pranadhini, S.A. (2006). Hubungan antara dimensi uncertainty avoidance dengan gaya pengambilan keputusan pada suku bangsa Jawa dan Minangkabau (studi pada karyawan Bank X) [Skripsi tidak diterbitkan]. Universitas Indonesia.

Ramayah, T., \& Harun, Z. (2005). Entrepreneurial intention among the students of USM. International Journal of Management and Entrepreneurship, 1(1), 8-20.

Redpath, L., \& Nielsen, M.O. (1997). A comparison of native culture, nonnative culture and new management ideology. Canadian Journal of Administrative Sciences, 14(3), 327339.

The Global Entrepreneurship and Development Institute. (2018). 2018 global entrepreneurship index. https://thegedi.org/globalentrepreneurship-and-developmentindex/

Wagner, J. A., \& Hollenbeck, J. R. (1995). Management of organizational behaviour (2nd ed.). Prentice Hall.

Wennekers, S., Thurik, R., Stel, A., \& Noorderhaven, N. (2007). Uncertainty avoidance and the rate of business ownership across 21 OECD countries, 1976-2004. Journal of Evolutionary Economics, 17(2), 133-160.

Wijanto, S. H. (2008). Structural equation modeling dengan Lisrel 8.8: Konsep dan tutorial. Graha Ilmu.

Zimmerer, T. W., \& Scarborough, N. M. (2002). Essentials of entrepreneurship and small businesses management. Pearson Education. 